Bull. Fac .Agric., Cairo Univ.Vol. 68:79-87: (2017).

\title{
PERFORMANCE OF THREE BREAD WHEAT CULTIVARS UNDER DIFFERENT SOWING PATTERNS
}

\author{
(Received:23.1.2017) \\ By \\ D.A. A. El Hag and R.F. El Mantawy* \\ Agronomy Department, Faculty of Agriculture, Kafrelsheikh University, Egypt. \\ * Plant Physiology Research Department, Field Crops Research Institute, \\ Agricultural Research Center, Giza, Egypt.
}

\begin{abstract}
Two field experiments were conducted in 2013/14 and 2014/15 growing seasons at the Faculty of Agriculture,Kafrelsheikh University, to study the impact of sowing pattern on grain yield and yield contributing parameters of three Egyptian bread wheat cultivars. A strip plot design with three replications was used. Three sowing patterns (Broadcast, Drill and Bed.) were assigned in the horizontal plots. The three bread wheat cultivars (Misr 1, Misr 2 and Gemmeiza 9) were randomly distributed in vertical plots. The number of days to heading and maturity, plant height, flag leaf area, the number of fertile tiller $/ \mathrm{m}^{-2}, 1000$-grain weight, the number of grains/spike, grain yield, straw yield, harvest index (\%) and grain filling rate were studied. The most important results could be summarized as follows: sowing pattern significantly affected number of days to heading and harvest index in the $1^{\text {st. }}$ season, whereas the number of fertile tillers, 1000-grain weight, the number of grains/spike, straw yield and grain filling rate in both seasons. There were highly significant differences among wheat cultivars for all the studied characters. Gemmeiza 9 recorded the highest number of days to heading and the number of days to maturity, plant height, flag leaf area, 1000-grain weight and the number of grains/spike in both seasons, and Misr 1 and 2 in 2013/14 and Misr 2 in 2014/15 recorded the highest harvest index. The results indicated also that Misr 2 produced the highest grain yield, straw yield and grain filling rate in both seasons. Misr 2 produced the highest grain yield, straw yield under drill sowing pattern in both seasons. Drill sowing pattern wasr the best sowing for all cultivars under this investigation.
\end{abstract}

Key words: bread wheat, sowing pattern, grain yield, yield component.

\section{INTRODUCTION}

Wheat (Triticum aestivum, L.) is the most strategic cereal crop in the world as well as in Egypt. The properties of its grain make it the main leading cereal for human food. The increasing demands of wheat is mainly due to the fast growth of human population, therefore maximizing wheat production should be achieved through cultivation of the high yielding cultivars and appropriate agronomic practices such as irrigation, sowing patterns, seed rate, seeding date, fertilizer and weed control. In Egypt, there are different wheat sowing patterns such as broadcasting (as a common practice), drilling in rows and also in hills on ridges of proceeding crops, i.e. cotton or maize in particular when harvest of these crops is delayed. Considerable research has been conducted on the sowing patterns. There are some benefits of this sowing system such as reducing seed rate, better and saving irrigation management facilities, reducing crop lodging and herbicide dependence, the control of root diseases and better usage of chemical application machines. Khan et al. (2007), Soomro et al. (2009), Amin et al. (2010), Saad (2010), Shahid et al. (2011), Wang et al. (2011), Ali et al. (2012), Fakkar and Amen (2012), Kahloom et al.(2012), Genedy (2014), Omar et al. (2014) and EL-Hawary and Shahein (2015) reported that there were significant differences in the number of days to heading and maturity, plant height, the number of fertile tillers $/ \mathrm{m}^{2}$, the number of grains/spike, 1000-grain weight, grain yield, straw yield, harvest index and grain filling rate due to sowing pattern.

Many investigators reported that the number of days to maturity, maturity duration, grain 
filling rate, plant height, flag leaf area, number of spike $\mathrm{m}^{-2}$, number of grains spike ${ }^{-1}, 1000$ grain weight, biological yield, harvest index and grain yield were significantly affected by wheat cultivars (Moayedi et al., 2010; Sharshar, 2010; El hag-Walaa, 2012; Kahloom et al., 2012; Mushtaq et al., 2012; Singh and Singh, 2013; Omar et al., 2014; El hag-Dalia, 2016 and Kandil et al., 2016). Therefore, the main objective of the present investigation was to determine the sowing patterns to achieve maximum yield of wheat productions in north delta region.

\section{MATERIALS AND METHODS}

Tow field experiments were conducted at the Faculty of Agriculture-Kafrelsheikh University to study the effect of three sowing pattern on three bread wheat cultivars, during 2013/2014 and 2014/2015 seasons. Strip plot design with three replications was used.

\subsection{Three sowing patterns were allocated in vertical plots}

2.1.1. Drill sowing: drilling in rows on flat land. The net of each plot area was $8.4 \mathrm{~m}^{2}$ (12 rows) $3.5 \mathrm{~m}$ and $20 \mathrm{~cm}$ apart.Plot area is $2.4 \times 3.5=8.4$ $\mathrm{m}^{2}$.

2.1.2. Bed sowing: drilling five rows on bed, (20 $\mathrm{cm}$ apart). Each plot consisted of two beds and width of bed $120 \mathrm{~cm}$. The net plot area was 8.4 $\mathrm{m}^{2}$, (3.5 m length $\left.\mathrm{x} 2.4\right)$.

2.1.3. Broadcasting sowing:

Broadcast on flat land.Plot area $2.4 \times 3.5=8.4 \mathrm{~m}^{2}$. 2.2. Three bread wheat cultivars (Misr 1, Misr 2 and Gemmeiza 9) were randomly distributed in horizontal plots (Table 1).

Table(1): Name and pedigree of the three wheat cultivars.

\begin{tabular}{|c|l|}
\hline Name & \multicolumn{1}{|c|}{ Pedigree } \\
\hline Misr 1 & OASIS/SKAUZA//4*BCN/3/ \\
& 2*PASTOR \\
& CMSSOOYO1881T-OSOM-30Y- \\
& 030M-030WGY-33M-OY-OS \\
\hline Misr 2 & Skauz/Bar 92 \\
\hline Gemmeiza 9 & Ald"S"/Huas//Cmh 74A. 630/Sx \\
& CGM 4583-5GM-1GM-OGM \\
\hline
\end{tabular}

Wheat grains were sown at the rate of 350 seeds $/ \mathrm{m}^{2}$ by using the previously mentioned sowing patterns. Nitrogen fertilizer at the rate of $70 \mathrm{~kg} \mathrm{~N} / \mathrm{fed}$ in the form of Urea $(46.5 \% \mathrm{~N})$ was applied in three doses $20 \%$ at the seedling stage, $40 \%$ at tillering and $40 \%$ at the joint stage. The preceding summer crop was rice (Oriza sativa, L.) in both seasons. The experiments were carried out in clay loam soil with medium fertility.

The experimental field was well prepared and calcium super phosphate $\left(15.5 \% \mathrm{P}_{2} \mathrm{O}_{5}\right)$ at the rate of $100 \mathrm{~kg} / \mathrm{fed}$. was applied during soil preparation. Sowing was on November the $4^{\text {th }}$ week in both seasons. The common agricultural practices for growing wheat according to the recommendations of Ministry of Agriculture, Egypt, were followed, except the factors under study.

In both seasons, the following traits were estimated:-

2.2.1. At growth stage: Number of days to $50 \%$ heading (HD), number of days to physiological mature (MD), flag leaf area (FLA).

2.2.2. At harvest time: plant height (PLH), number of fertile tiller $/ \mathrm{m}^{-2}\left(\mathrm{~S} / \mathrm{m}^{2}\right)$, 1000-grain weight (TGW), number of grains/spike (G/S), grain yield (GY), straw yield (SY) and harvest index \% (HI \%), grain filling rate $\mathrm{kg} /$ day/fed.= grain yield $(\mathrm{kg} / \mathrm{fed}$.) / maturity duration (days). Grain yield and straw yield were converted into ton/fed.

\subsection{Statistical analysis}

All data collected for the two seasons were subjected to analysis of variance and means of treatment were compared according to Duncun Multiple Range Test (Duncan, 1955).. All statistical analysis was performed using analysis of variance technique by "MSTATC (1990)" computer software package.

\section{RESULTS AND DISCUSSION \\ 3.1. Number of days to heading}

Sowing pattern influenced significantly $(\mathrm{P}>0.05)$ the number of days to heading in the first season. Broadcasting pattern recorded the highest number of days to heading (105.8 days) in the first season. Broadcast pattern gave good spaces between seed and seed than sowing in row,as this method gave plants better aeration, light, and nutrient, which caused more vegetative growth. Similar results were obtained by several researchers, e.g. Saad (2010), Mushtaq et al. (2012), Singh and Singh (2013), Genedy (2014), Omar et al., (2014) and ELHawary and Alaa-Shahein (2015). Meanwhile, the differences due to cultivars were significant ( $P>0.01)$ for the number of days to heading in both seasons. Gemmeiza 9 recorded the maximum number of days to heading (106.4 and 103.4 days) in both seasons, respectively (Table 2). The differences among cultivars are mainly due to both genetical and environmental 
Table (2): Effect of sowing patterns and wheat cultivars on the number of days to $50 \%$ heading, the number of days to maturity. Plant height and their interaction in 2013/14 and 2014/2015 seasons.

\begin{tabular}{|c|c|c|c|c|c|c|}
\hline \multirow[t]{2}{*}{ Treatment } & \multicolumn{2}{|c|}{$\begin{array}{l}\text { Number of days } \\
\text { to } 50 \% \text { heading }\end{array}$} & \multicolumn{2}{|c|}{$\begin{array}{c}\text { Number of days } \\
\text { to maturity }\end{array}$} & \multicolumn{2}{|c|}{ Plant height (cm) } \\
\hline & $2013 / 14$ & $2014 / 15$ & $2013 / 14$ & $2014 / 15$ & $2013 / 14$ & $2014 / 15$ \\
\hline \multicolumn{7}{|c|}{ Sowing pattern } \\
\hline Broadcasting & $105.8 \mathrm{a}$ & 102.0 & 146.6 & 147.8 & 112.8 & 114.8 \\
\hline Drill & $103.0 \mathrm{c}$ & 98.9 & 145.3 & 146.6 & 114.8 & 116.2 \\
\hline Bed & $104.9 \mathrm{~b}$ & 99.7 & 145.4 & 147.9 & 116.9 & 118.3 \\
\hline F test & $*$ & NS & NS & NS & NS & NS \\
\hline \multicolumn{7}{|c|}{ Wheat cultivar } \\
\hline Misr 1 & $102.8 \mathrm{c}$ & $97.7 \mathrm{c}$ & $142.2 \mathrm{c}$ & $143.8 \mathrm{c}$ & $110.1 \mathrm{c}$ & $112.1 \mathrm{c}$ \\
\hline Misr 2 & $104.4 \mathrm{~b}$ & $99.4 \mathrm{~b}$ & $144.2 \mathrm{~b}$ & $145.2 \mathrm{~b}$ & $114.7 \mathrm{~b}$ & $116.8 \mathrm{~b}$ \\
\hline Gemmeiza 9 & $106.4 \mathrm{a}$ & $103.4 \mathrm{a}$ & $150.9 \mathrm{a}$ & $153.2 \mathrm{a}$ & $119.7 \mathrm{a}$ & $120.4 \mathrm{a}$ \\
\hline F test & $* *$ & $* *$ & $* *$ & $* *$ & $* *$ & $* *$ \\
\hline \multicolumn{7}{|c|}{ Interaction effect } \\
\hline & NS & NS & $*$ & NS & NS & NS \\
\hline
\end{tabular}

$* *, *$ and NS indicated $\mathrm{P}<0.01,0.05$ and not significant, respectively.

Means designated by the same letter are not significantly different at 5\%level according to Duncan's Multiple Range Test.

variations. Difference in heading dates among wheat genotypes may be due to the genetic constitution, which is seriously affected by environmental conditions. These results are in agreement with those obtained by Sharshar (2010), El Hag Walaaa (2011), El hag-Dalia (2012), Omar et al. (2014), EL-Hawary and Alaa-Shahein (2015), El hag-Dalia (2016) and Kandil et al. (2016).

The interaction effects between sowing pattern and wheat cultivars were insignificant for number of days to heading.

\subsection{Number of days to maturity}

Sowing pattern showed insignificant effect on the number of days to maturity in 2013/14 and $2014 / 15$. There were significant $(P>0.01)$ effects for the number of days to maturity in both seasons among the three cultivars. These findings are in harmony with those reported by Saad (2010), Mushtaq et al. (2012), Singh and Singh (2013), Genedy (2014) and EL-Hawary and Alaa-Shahein (2015). The maximum number of days to maturity (150.9 and 153.2 days) was recorded for Gemmeiza 9 cultivar in both seasons, respectively (Table 2). The differences between cultivars were mainly due to both of genetical and environmental variations (Table 2). These results are in agreement with those obtained by several researchers e.g. El hag-Dalia (2012), Omar et al. (2014), ELHawary and Alaa-Shahein (2015) El hag-Dalia (2016) and Kandil et al. (2016).

The interaction effects between sowing pattern and wheat cultivars were significant $(\mathrm{P}>0.05)$ for the number of days to maturity in the first season only (Table 2).Gemmeiza 9 recorded the highest values (155.3 days) under bed sowing pattern (Table 3 ).

\subsection{Plant height $(\mathrm{cm})$}

The three sowing patterns (broadcasting, drill and bed) did not influence plant height in wheat during both seasons. Meanwhile, the cultivars had significant $(\mathrm{P} 0.0>1)$ effect on plant height in both seasons. The tallest plants in both seasons were (119.7 and $120.4 \mathrm{~cm})$ for Gemmeiza 9 cultivar. Meanwhile, Misr 1 produced the shortest plant (110.1 and 112.1 $\mathrm{cm})$. Differences in plant height among the wheat cultivars may be attributed to their different genetic background as well as their interaction with the environmental factors. These results are in a good accordance with those obtained by El hag-Dalia (2012), Omar et al., (2014), EL-Hawary and Alaa-Shahein (2015) El hag-Dalia (2016). Kandil et al.(2016).There was insignificant effect for the interaction between sowing pattern and wheat cultivars for plant height in both seasons (Table 2).

\subsection{Flag leaf area $\left(\mathrm{cm}^{2}\right)$}

Sowing patterns broadcasting, drill or bed were unaffected on flag leaf area $\left(\mathrm{cm}^{2}\right)$ in wheat cultivars during both seasons (Table 4). Wheat cultivars significantly $(\mathrm{P}>0.01)$ affected flag leaf area $\left(\mathrm{cm}^{2}\right)$ in both seasons. Gemmeiza 9 recorded the maximum flag leaf area (45.8, and $\left.47.0 \mathrm{~cm}^{2}\right)$. On the other hand, Misr 1 recorded the minimum flag leaf area $\left(39.8\right.$ and $\left.42.2 \mathrm{~cm}^{2}\right)$. Similar results were obtained by several researchers, e.g. El hag-Dalia (2012), Omar et al., (2014) El hag-Dalia (2016) and Kandil et al. (2016). Gemmeiza 9 recorded the maximum flag leaf area $\left(48.7 \mathrm{~cm}^{2}\right)$ meanwhile, Misr 1 
Table (3): Mean of the number of days to maturity and flag leaf area in 2014/15, 1000-grain weight in 2013/14 as affected by the interaction between sowing pattern and wheat cultivars.

\begin{tabular}{|c|c|c|c|c|}
\hline \multirow{2}{*}{ Cultivar } & \multirow{2}{*}{ Sowing pattern } & $\begin{array}{c}\text { Number of } \\
\text { days to } \\
\text { maturity }\end{array}$ & $\begin{array}{c}\text { Flag leaf area } \\
\left(\mathbf{c m}^{\mathbf{2}}\right)\end{array}$ & $\begin{array}{c}\text { 1000-grain } \\
\text { weight }(\mathbf{g})\end{array}$ \\
\cline { 2 - 5 } & $\mathbf{2 0 1 4 / 2 0 1 5}$ & $\mathbf{2 0 1 4 / 2 0 1 5}$ & $\mathbf{2 0 1 3 / 2 0 1 4}$ \\
\hline Misr 1 & broadcast & $144.6 \mathrm{~cd}$ & $41.3 \mathrm{f}$ & $41.9 \mathrm{~cd}$ \\
\hline & drill & $146.0 \mathrm{c}$ & $43.3 \mathrm{e}$ & $43.0 \mathrm{c}$ \\
\hline & bed & $152.6 \mathrm{~b}$ & $42.0 \mathrm{f}$ & $44.3 \mathrm{ab}$ \\
\hline Misr 2 & broadcast & $143.3 \mathrm{e}$ & $46.3 \mathrm{bc}$ & $43.6 \mathrm{~b}$ \\
\hline & drill & $144.7 \mathrm{~d}$ & $45.3 \mathrm{~cd}$ & $43.5 \mathrm{~b}$ \\
\hline Gemmeiza 9 & bed & $151.6 \mathrm{~b}$ & $43.7 \mathrm{e}$ & $45.0 \mathrm{a}$ \\
\hline & broadcast & $143.3 \mathrm{e}$ & $48.7 \mathrm{a}$ & $39.3 \mathrm{e}$ \\
\hline drill & $145.0 \mathrm{c}$ & $47.3 \mathrm{~b}$ & $40.7 \mathrm{~d}$ \\
\hline F test & bed & $155.3 \mathrm{a}$ & $45.0 \mathrm{~d}$ & $42.7 \mathrm{c}$ \\
\hline
\end{tabular}

**, * and NS indicated $\mathrm{P}<0.01,0.05$ and not significant, respectively.

Means designated by the same letter are not significantly different at $5 \%$ level according to Duncan's Multiple Range Test.

recorded the minimum flag leaf area $\left(41.3 \mathrm{~cm}^{2}\right)$ under broadcasting pattern in the second season (Table 3).

\subsection{Number of spikes $/ \mathrm{m}^{2}$}

Sowing pattern influenced significantly $(\mathrm{P}>0.05$ and $>0.01)$ the number of spike $/ \mathrm{m}^{2}$ during the first and second seasons, respectively. The results presented in (Table 4) showed that broadcasting pattern produced the maximum number of spikes $/ \mathrm{m}^{2}$ (376.0 and, 398.6) in the first and second seasons, respectively. Meanwhile, the minimum number of spikes $/ \mathrm{m}^{2}$ (368.3 and 362.6) was produced by sowing on bed pattern. These significant differences may be due to non-competition which led to available minerals and good aeration. Similar results were obtained by Saad (2010), Mushtaq et al., (2012) , Singh and Singh (2013), Genedy (2014) and, Omar et al. (2014) and EL-Hawary and AlaaShahein (2015). Wheat cultivars significantly influenced $(\mathrm{P}>0.05)$ the number of spike $/ \mathrm{m}^{2}$ in the first season and highly significant $(\mathrm{P}>0.01)$ in the second season. The results presented in Table 4 showed that Misr 2 produced the maximum number of spikes $/ \mathrm{m}^{2}$ (379.9 and 391.1) in the first and second seasons, respectively. Differences among wheat cultivars may be attributed to their different genetic background as well as their interaction with the environmental factors. These results are in a good accordance with those obtained by Sharshar (2010), El Hag Walaaa (2011), El hagDalia (2012), Omar et al. (2014), EL-Hawary and Alaa-Shahein (2015), El hag-Dalia (2016) and Kandil et al. (2016). The interaction between wheat cultivars and sowing pattern had insignificant effect on the number of spikes $/ \mathrm{m}^{2}$.

\subsection{Thousand grain weight (g)}

Sowing pattern influenced significantly ( $\mathrm{P}>0.05$ ) 1000-grain-weight (44.0 $\mathrm{g}$ in 2013/14 and 43.3 and $42.2 \mathrm{~g}$ ) during both seasons. The results presented in Table (4) showed that the maximum 1000- grain weights were produced with drill pattern with bed and drill sowing pattern in the second season. Thousand kernel weight is an important component that has great contribution in wheat grain yield. This trait was highly affected by environmental conditions especially soil moisture and temperature during grain filling. Similar results were obtained by several researchers, e.g. Saad (2010), Sharshar (2010), Mushtaq et al. (2012), Singh and Singh (2013), Genedy (2014), Omar et al. (2014) and EL-Hawary and Alaa-Shahein (2015). Wheat cultivars significantly influenced (P.>0.01) 1000 grain weight in both seasons. The results presented in Table (4) showed that Gemmeiza 9 produced the highest 1000 -grain weight $(44.0 \mathrm{~g}$ and $43.8 \mathrm{~g}$ ) in the first and second seasons, respectively. On the other hand, Misr 1 recorded the lowest values (41.6 and $40.7 \mathrm{~g}$ ) in both seasons, respectively. Such results are in harmony with those reported by Sharshar (2010), El hag-walaa (2011), Omar et al.(2014), ELHawary and Alaa-Shahein (2015), El hag-Dalia 
Table (4): Effect of sowing pattern and wheat cultivars on, flag leaf area, the number of spike/ $\mathrm{m}^{2}$ and 1000-grain weight and their interaction in 2013/14 and 2014/15 seasons.

\begin{tabular}{|c|c|c|c|c|c|c|}
\hline Treatment & \multicolumn{2}{|c|}{ Flag leaf area $\left(\mathbf{c m}^{2}\right)$} & \multicolumn{2}{c|}{$\begin{array}{c}\text { No. spikes/m grain weight } \\
\text { ( g) }\end{array}$} \\
\hline & $\mathbf{2 0 1 3 / 1 4}$ & $\mathbf{2 0 1 4 / 1 5}$ & $\mathbf{2 0 1 3 / 1 4}$ & $\mathbf{2 0 1 4 / 1 5}$ & $\mathbf{2 0 1 3 / 1 4}$ & $\mathbf{2 0 1 4 / 1 5}$ \\
\hline \multicolumn{7}{|c|}{ Sowing pattern } \\
\hline Broadcasting & 43.11 & 45.4 & $376.0 \mathrm{a}$ & $398.6 \mathrm{a}$ & $43.1 \mathrm{~b}$ & $41.5 \mathrm{~b}$ \\
\hline Drill & 44.22 & 45.3 & $366.7 \mathrm{~b}$ & $385.4 \mathrm{ab}$ & $44.0 \mathrm{a}$ & $42.2 \mathrm{ab}$ \\
\hline Bed & 42.00 & 43.6 & $368.3 \mathrm{~b}$ & $362.6 \mathrm{~b}$ & $40.9 \mathrm{c}$ & $43.3 \mathrm{a}$ \\
\hline F test & $\mathrm{NS}$ & $\mathrm{NS}$ & $*$ & $* *$ & $*$ & $*$ \\
\hline \multicolumn{7}{|c|}{ Wheat cultivar } \\
\hline Misr 1 & $39.8 \mathrm{c}$ & $42.2 \mathrm{c}$ & $363.3 \mathrm{~b}$ & $375.4 \mathrm{c}$ & $41.6 \mathrm{~b}$ & $40.7 \mathrm{c}$ \\
\hline Misr 2 & $43.8 \mathrm{~b}$ & $45.1 \mathrm{~b}$ & $379.9 \mathrm{a}$ & $391.1 \mathrm{a}$ & $42.4 \mathrm{~b}$ & $42.67 \mathrm{~b}$ \\
\hline Gemmeiza 9 & $45.8 \mathrm{a}$ & $47.0 \mathrm{a}$ & $367.8 \mathrm{~b}$ & $380 \mathrm{~b}$ & $44.0 \mathrm{a}$ & $43.78 \mathrm{a}$ \\
\hline F test & $* *$ & $* *$ & $*$ & $* *$ & $* *$ & $* *$ \\
\hline \multicolumn{7}{|c|}{ Interaction effect } \\
\hline
\end{tabular}

**, * and NS indicated $\mathrm{P}<0.01,0.05$ and not significant, respectively.

Means designated by the same letter are not significantly different at $5 \%$ level according to Duncan's Multiple

(2016) and Kandil et al.(2016). The interaction between wheat cultivars and sowing pattern was significant $(\mathrm{P}>0.05)$ in the first season. Misr 2 recorded the highest values $(45.0 \mathrm{~g})$ under bed pattern in 2013/14 (Table 3).

\subsection{Number of grains/spike}

It is clear from the results shown in Table(5) that the effect of sowing pattern was significant $(\mathrm{P}>0.01)$ on the number of grains/spike. Broadcast pattern produced the highest number of grain/spike (70.8 and 69.3) in both seasons, respectively. Similar results were obtained by several researchers, e.g. Omar et al. (2014), Genedy (2014), EL-Hawary and Alaa-Shahein (2015). The number of grain/spike differed significantly $(\mathrm{P}>0.01)$ among wheat cultivars. Gemmeiza 9 produced the maximum number (66.0 and 68.0) in both seasons, respectively. Similar results were obtained by several researchers, e.g. Sharshar (2010), El Hag-Walaa (2011), El hag-Dalia (2012), Omar et al., (2014), EL-Hawary and Alaa-Shahein (2015) El hagDalia (2016), and Kandil et al. (2016).

The interaction between wheat cultivars and sowing pattern was significant $(\mathrm{P}>0.05)$. Misr 2 recorded the highest values (72.7) under broadcast pattern in 2013/14 (Table 6).

\subsection{Grain yield (t/fed.)}

The results presented in Table (5) for grain yield revealed that non of the sowing pattern influenced grain yield during both seasons. Drill Pattern recorded the highest yield without significance with other sowing pattern. The results indicate that proper sowing pattern increased plant vitality and yield. It encourages nutrient respectively. Similar results were availability, good soil environment for up take soil nutrient and water use efficiency (Hossain and Maniruzzaman (1992), all necessary for crop vigor and yield. Broadcasting pattern is considered inferior than other (Collina et al., 1992). Increasing grain yield with increasing number of spikes $/ \mathrm{m}^{2}$, number of grains/spike, 1000-grain weight had attributed to the increase in yield components values. These results were suggested by Saad (2010), Mushtaq et al. (2012),Singh and Singh (2013), Genedy (2014), Omar et al. (2014) and EL-Hawary and AlaaShahein (2015). The results presented in Table(5) show a significant $(\mathrm{P}>0.05$ and 0.01$)$ effect for wheat cultivars on grain yield in both seasons, respectively. Misr 2 produced the maximum grain yield (3.618 and $3.510 \mathrm{t} / \mathrm{fed}$.) in the first and second seasons, respectively. Similar results were obtained by several researchers; El hag-walaa (2011), El hag-Dalia (2012), Omar et al. (2014), EL-Hawary and Alaa-Shahein (2015) El hag-Dalia (2016) and Kandil et al. (2016). The interaction between wheat cultivars and sowing pattern was significant $(\mathrm{P}>0.01)$ in $2014 / 15$ season. Results presented in Table (6) indicated that wheat cultivar Misr 2 produced the highest grain yield (3.73 t/fed.) under drill sowing pattern.

\subsection{Straw yield (t/fed.)}

Results presented in Table 5 show that the effect of sowing patter was significant $(\mathrm{P}>0.05)$ in both seasons. The highest straw yields (6.151 and $5.815 \mathrm{t} / \mathrm{fed}$.) were produced under drill pattern in both seasons, respectively . However, bed pattern produced the lowest straw yield (5.281 and5.324 t/fed.) in both seasons, obtained 
Table (5): Effect of sowing pattern and wheat cultivars on the number of grain/spike, grain yield and straw yield and their interaction effects of wheat in 2013/14 and 2014/15 seasons.

\begin{tabular}{|c|c|c|c|c|c|c|}
\hline \multirow[t]{2}{*}{ Treatment } & \multicolumn{2}{|c|}{ No. grains/spike } & \multicolumn{2}{|c|}{ Grain yield (t/fed.) } & \multicolumn{2}{|c|}{ Straw yield (t/fed.) } \\
\hline & $2013 / 14$ & $2014 / 15$ & $2013 / 14$ & $2014 / 15$ & $2013 / 14$ & $2014 / 15$ \\
\hline \multicolumn{7}{|c|}{$\begin{array}{l}\text { Sowing pattern } \\
\end{array}$} \\
\hline Broadcasting & $70.8 \mathrm{a}$ & $69.3 a$ & 3.328 & 3.223 & $5.569 \mathrm{~b}$ & $5.335 b$ \\
\hline Drill & $64.9 \mathrm{~b}$ & $63.9 \mathrm{~b}$ & 3.482 & 3.460 & $6.151 \mathrm{a}$ & $5.815 \mathrm{a}$ \\
\hline Bed & $60.3 c$ & $64.6 \mathrm{~b}$ & 3.343 & 3.232 & $5.281 \mathrm{~b}$ & $5.324 b$ \\
\hline F test & $* *$ & $* *$ & NS & NS & $*$ & $*$ \\
\hline \multicolumn{7}{|c|}{ Wheat cultivar } \\
\hline Misr 1 & $63.5 b$ & $64.0 \mathrm{c}$ & $3.425 \mathrm{~b}$ & $3.188 \mathrm{~b}$ & $5.464 \mathrm{c}$ & 5.390 \\
\hline Misr 2 & $66.4 \mathrm{a}$ & $65.8 \mathrm{~b}$ & $3.618 \mathrm{a}$ & $3.510 \mathrm{a}$ & $5.859 \mathrm{a}$ & 5.582 \\
\hline Gemmeiza 9 & $66.0 \mathrm{a}$ & $68.0 \mathrm{a}$ & $3.111 \mathrm{c}$ & $3.218 \mathrm{~b}$ & $5.678 \mathrm{~b}$ & 5.502 \\
\hline F test & $* *$ & $* *$ & $*$ & $* *$ & $* *$ & $\mathrm{NS}$ \\
\hline \multicolumn{7}{|c|}{ Interaction effect } \\
\hline & $*$ & NS & $\mathrm{NS}$ & $* *$ & NS & $*$ \\
\hline
\end{tabular}

$* *, *$ and NS indicated $\mathrm{P}<0.01,0.05$ and not significant, respectively.

Means designated by the same letter are not significantly different at 5\% level according to Duncan's Multiple Range Test.

Table (6): Number of grains/spike (2013/2014), grain yield (2014/2015) and straw yield (2014/2015) as affected by the interaction between sowing pattern and wheat cultivars.

\begin{tabular}{|c|c|c|c|c|}
\hline \multirow{2}{*}{ Cultivar } & \multirow{2}{*}{ Sowing pattern } & $\begin{array}{c}\text { Number of } \\
\text { grains/spike }\end{array}$ & $\begin{array}{c}\text { Grain yield } \\
\text { (t/fed.) }\end{array}$ & $\begin{array}{c}\text { Straw yield } \\
\text { (t/fed.) }\end{array}$ \\
\cline { 2 - 5 } & 2013/14 & $\mathbf{2 0 1 4 / 1 5}$ & $\mathbf{2 0 1 4 / 1 5}$ \\
\hline Misr 1 & broadcast & $69.3 \mathrm{~b}$ & $3.17 \mathrm{de}$ & $5.27 \mathrm{~cd}$ \\
\hline & drill & $64.0 \mathrm{~cd}$ & $3.28 \mathrm{~cd}$ & $5.85 \mathrm{ab}$ \\
\hline Misr 2 & bed & $57.2 \mathrm{f}$ & $3.12 \mathrm{ef}$ & $5.05 \mathrm{~d}$ \\
\hline & broadcast & $72.7 \mathrm{a}$ & $3.48 \mathrm{~b}$ & $5.53 \mathrm{bc}$ \\
\hline & drill & $66.3 \mathrm{c}$ & $3.73 \mathrm{a}$ & $5.94 \mathrm{a}$ \\
\hline Gemmeiza 9 & bed & $60.3 \mathrm{e}$ & $3.32 \mathrm{c}$ & $5.28 \mathrm{~cd}$ \\
\hline & broadcast & $70.3 \mathrm{ab}$ & $3.02 \mathrm{f}$ & $5.21 \mathrm{~cd}$ \\
\hline & drill & $64.3 \mathrm{~cd}$ & $3.37 \mathrm{bc}$ & $5.66 \mathrm{ab}$ \\
\hline F test & bed & $63.3 \mathrm{~d}$ & $3.26 \mathrm{~cd}$ & $5.64 \mathrm{ab}$ \\
\hline
\end{tabular}

**, * and NS indicated $\mathrm{P}<0.01,0.05$ and not significant, respectively.

Means designated by the same letter are not significantly different at $5 \%$ level according to Duncan's Multiple Range Test.

by several researchers, e.g. Saad (2010), Mushtaq et al. (2012), Singh and Singh (2013), Genedy (2014), Omar et al. (2014) and ELHawary and Alaa-Shahein (2015).

Straw yield differed significantly $(\mathrm{P}>0.01)$ among wheat cultivars in the first season. Misr 2 recorded the maximum straw yield (5.859 $\mathrm{t} / \mathrm{fed}$.). Similar results were obtained by several researchers, e.g. El hag-walaa (2011), El hagDalia (2012), Omar et al., (2014) El hag-Dalia (2016) and Kandil et al. (2016).The interaction between sowing pattern and wheat cultivars was significant $(\mathrm{P}>0.05)$ in the second season.Misr2 produced the highest straw yield $(5.94 \mathrm{t} / \mathrm{fed}$.) under drill sowing pattern (Table 6).

\subsection{Harvest index percentage}

Presented results in Table (7) for harvest index percentage revealed that sowing pattern broadcast, drill and bed influenced significant $(\mathrm{P}>0.05)$ harvest index in the first season. Bed sowing pattern was recorded the highest values harvest index $(38.57 \%)$. Similar results were obtained by several researchers e.g. Saad (2010), Mushtaq et al. (2012), Singh and Singh (2013), Genedy (2014), and EL-Hawary and AlaaShahein (2015).

The results in Table (7) for harvest index indicated that there were significant $(\mathrm{P}>0.01)$ deferences among wheat cultivars in both seasons. The maximum harvest index was recorded by Misr 1 (38.58\%) in 2013/14 and Misr $2(38.61 \%)$ in 2014/2015season. Similar results were obtained by several researchers e.g. El Hag-walaa (2011), El hag-Dalia (2012), Omar 
Table (7): Effect of sowing pattern and wheat cultivars on harvest index and grain filling rate and there interaction of wheat in 2013/14 and 2014/2015 seasons

\begin{tabular}{|c|c|c|c|c|}
\hline \multirow[t]{2}{*}{ Treatment } & \multicolumn{2}{|c|}{ Harvest index $(\%)$} & \multicolumn{2}{|c|}{ Grain filling rate (kg/day/fed.) } \\
\hline & 2013/14 & $2014 / 15$ & $2013 / 14$ & $2014 / 15$ \\
\hline \multicolumn{5}{|c|}{ Sowing pattern } \\
\hline Broadcasting & $37.38 \mathrm{~b}$ & 37.67 & $81.569 c$ & $70.371 b$ \\
\hline Drill & $36.16 \mathrm{c}$ & 37.28 & $82.317 b$ & $72.537 \mathrm{a}$ \\
\hline Bed & $38.57 \mathrm{a}$ & 37.80 & $82.543 \mathrm{a}$ & $67.054 \mathrm{c}$ \\
\hline F test & $*$ & NS & $*$ & $* *$ \\
\hline \multicolumn{5}{|c|}{ Wheat cultivar } \\
\hline Misr 1 & $38.58 \mathrm{a}$ & $37.24 \mathrm{~b}$ & $86.929 b$ & $69.154 b$ \\
\hline Misr 2 & $38.27 \mathrm{ab}$ & $38.61 \mathrm{a}$ & $90.905 \mathrm{a}$ & $76.638 \mathrm{a}$ \\
\hline Gemmeiza 9 & $35.44 \mathrm{~b}$ & $36.89 \mathrm{~b}$ & $69.910 \mathrm{c}$ & $64.618 \mathrm{c}$ \\
\hline F test & $* *$ & $* *$ & $* *$ & $* *$ \\
\hline \multicolumn{5}{|c|}{ Interaction effect } \\
\hline & NS & $\mathrm{NS}$ & NS & NS \\
\hline
\end{tabular}

**, * and NS indicated $\mathrm{P}<0.01,0.05$ and not significant, respectively.

Means designated by the same letter are not significantly different at $5 \%$ level according to Duncan's Multiple Range Test.

et al. (2014), EL-Hawary and Alaa-Shahein (2015), El hag-Dalia (2016) and Kandil et al. (2016). The interaction effects between wheat cultivars and sowing pattern were insignificant on harvest index in both seasons.

\subsection{Grain filling rate $(\mathrm{kg} / \mathrm{day} / \mathrm{fed}$.)}

Results presented in (Table 6) revealed that sowing pattern influenced significantly $(\mathrm{P}>0.05$ and 0.01 ) for grain falling rate in both seasons, respectively. In the first season, bed sowing pattern recorded the highest grain filling rate (82.543 kg/day/fed.). Moreover, drill sowing pattern recorded the highest values (72.537 $\mathrm{kg} /$ day/fed.) in the second season. These results are similar to those obtained by Omar et al., (2014). The differences among wheat cultivars were highly significant. Misr 2 recorded the highest values $(90.905$ and $76.638 \mathrm{~kg} /$ day/fed.) in both seasons, respectively. These results agreed with those obtained by El hag (2011), El hag (2012), Omar et al. (2014) and El hagDalia (2016). The interaction effects between wheat cultivars and sowing pattern was insignificant on grain filling rat in both seasons.

\section{REFERENCES}

Ali M., Ali L., Waqar M.Q. and Ali M.A. (2012). Bed sowing: A new crop establishment method for wheat (Triticum aestivum L.) Int. J. Agric. Appl. Sci., 4 (1): 834-841.

Amin E.H.M., Ibrahim A.A., Saleh M.E. and Ali A.G.A. (2010). Response of wheat cultivars to varying time of $\mathrm{N}$-application, sowing densities and sowing date. Zagazig J. Agric. Res., 37 (4): 803-828.
Collina B. A. and Fowier D. B. (1992). A comparison of broadcast and drill method for no-till seeding winter wheat. Canda J. Plant Sci.,(72):1001-1008.

Duncun D.B. (1955). Multiple range and multiple F test. Biometrics, 11: 1-42.

El hag-Dalia A. A. (2012). Effect of sowing date and nitrogen level on yield and quality of bread and durum wheat. Ph D. Thesis, Kafrelsheikh Univ., Egypt.

El hag-Dalia A. A. (2016). Effect of seeding rates on yield and yield components of two bread wheat cultivars. J. Agric. Res. Kafr El-Sheikh Univ. 42 (1): 29-43.

El hag-Walaa A. A. (2011). Evaluation of some cultivars and Lines of bread wheat under low inpout. M. Sc. Thesis, Kafrelsheikh Univ., Egypt.

EL-Hawary M. N. A and Alaa-Shahein M. E. A. (2015). Response of some wheat cultivars to sowing on bed under different nitrogen levels on some agronomic and quality traits. J. Agr. Res. Kafr El-Sheikh Univ., 41 (4) :1340-1354.

Fakkar A.A.O. and Amen E.A. (2012). Integration between sowing methods and mechanical weed control and their effect on wheat productivity. Aust. J. Basic Appl. Sci., 6 (13): 519-529.

Genedy M. S. A. Z. (2014). Effect of some sowing methods, nitrogen fertilization and irrigation on wheat grain yield. Ph. D. Thesis, Mansoura Univ., Egypt.

Hossain M. A. and Maniruzzaman A. F. M. (1992). Response of wheat ((Triticum aestivum, L.) to method of sowing and 
fertilizer placement. Indian J. Agron., 37:710-715.

Kahloom M.H., Iqbal M.F., Farooq M., Ali L., Fiaz M. and Ahmad I.(2012). A comparison of conservation technologies and traditional techniques for sowing of wheat. J. Anim.\& Plant Sci., 22 (3): 827-830.

Kandil A. A., Sharief A. E.M ., Seadh S.E. and Alta D. S. K. I.(2016). Role of humic acid and amino acids in limiting loss of nitrogen fertilizer and increasing productivity of some wheat cultivars grown under newly reclaimed sandy soil. Int. J. Adv. Res. Biol. Sci., 3 (4): 123-136.

Khan A., Arif M., Shan A.,Ali S., Hussain Z. and Khan S. (2007). Evaluation of sowing patterns for grain yield and yield components of wheat. Sarhad J. Agric., 23 (3):561-563.

Moayedi A. A., Boyce A. N. and Barakbah S. S. (2010). The Performance of Durum and Bread Wheat Cultivars Associated with Yield and Yield Component under Different Water Deficit Conditions. Aust. J. of Basic and Appl. Sci., 4 (1): 106-113.

MSTATC (1990). A Microcomputer program for Design Manegment and Analysis of Agronomic Research Experiments Michigan State Univ.

Mushtaq A., Liaqat A., Masood Q. W. and Ali M. A. (2012). Bed sowing: a new crop establishment method for wheat (Triticum aestivum L.) in cotton-wheat cropping system of southern Punjab. Int. J. Agric. Appl. Sci., 4 (1): 8-14.

Omar A. M., Mohamed A. A. E., Sharsher M. S. A. and Walaa-ElHag A.A. (2014)
Performance of some bread wheat genotypes under water regime and sowing methods. J. Agric. Res. Kafrelsheikh Univ. 40 (2):327-341.

Saad A. Solieman (2010). The influence of Triticum asetivum Seeding Rates and Sowing Patterns on the Vegetative Characteristics in Shambat Soil under Irrigation. Res. J. Agric.\& Biot. Sci., 6 (2): 93-102.

Shahid M.A., Ahmad N., Saleem M. and Akhtar B. (2011). Investigating optimum number of irrigations for wheat under raised bed technology in semi-arid climate. Int. J. Agric. Appl. Sci., 3 (2):89-93.

Sharshar A. M. (2010). Combining ability and heterosis for bread wheat under stress and normal irrigation treatments. M. Sc. Thesis, Kaferelsheikh Univ., Egypt.

Singh D. and Singh R. A. (2013). Effect of Wheat (Triticum aestivum L) Varieties to Sowing patterns and Time of Nitrogen Application in Late Sown Condition in Eastern Uttar Pradesh. Research. J. Agric. Sci., 4 (3): 341-346.

Soomro UA., Ur Rahman M., Odhano E. A., Gul S. and Tareen A. (2009). Effect of sowing pattern and seed rate on growth and yield of wheat (Triticum aestivum L.). World J. Agric. Sci., 5 (2):159-162.

Wang F., Kong L., Sayre K., Li1S., Si1 J., Feng B. and Zhang B. (2011). Morphological and yield responses of winter wheat (Triticum aestivum L.) to raised bed sowing in Northern China. Afr. J. Agric. Res., 6 (13): 2991-2997. 


$$
\begin{aligned}
& \text { سلوك بعض أصناف قمح الخبز تحت طرق الزراعة المختلفة } \\
& \text { داليا عبدربه عبد العزيز الحاج ـ رانيا فاروق المنطاوى }
\end{aligned}
$$

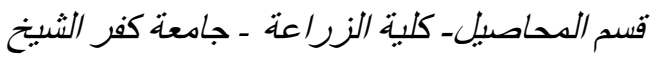

$$
\begin{aligned}
& \text { * قسم فسبولوجيا الدحاصيل- معهد بحوث المحاصيل الحقلية ـ مركز البحوث الزئ الزراعية }
\end{aligned}
$$

\section{ملخص}

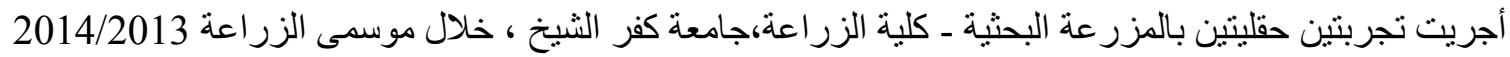

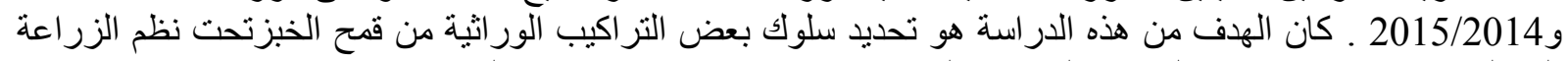

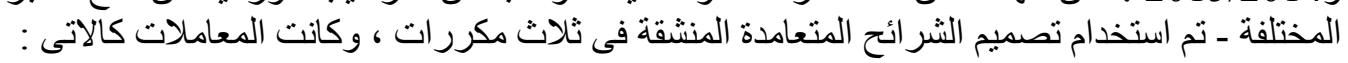

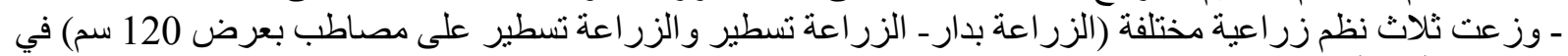

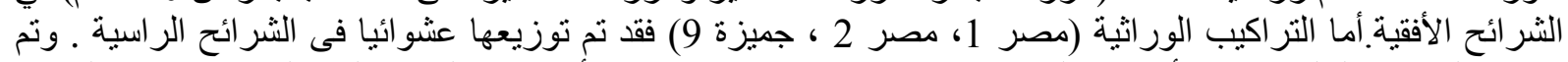

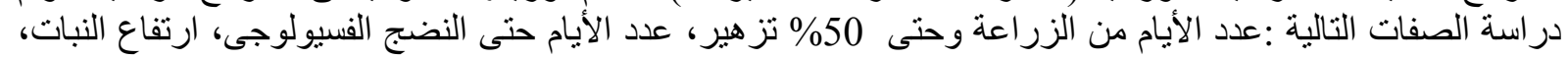

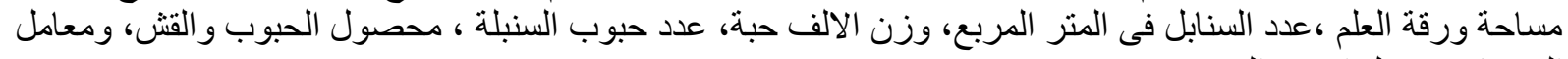

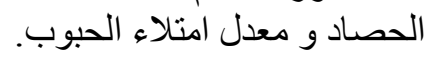

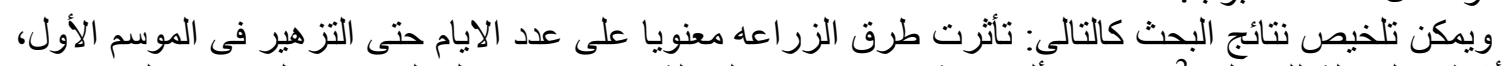

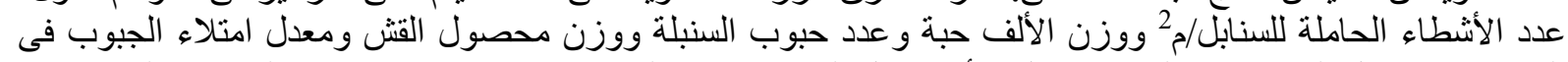

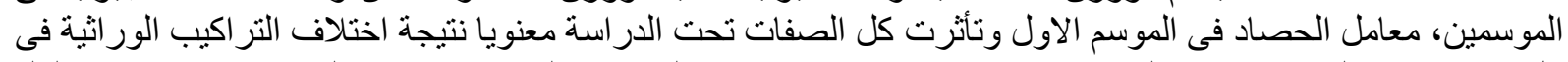

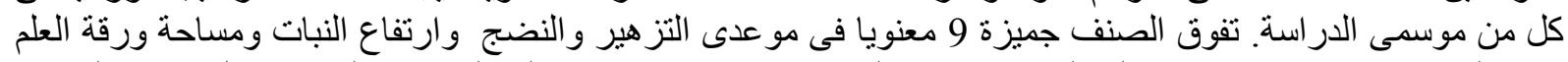

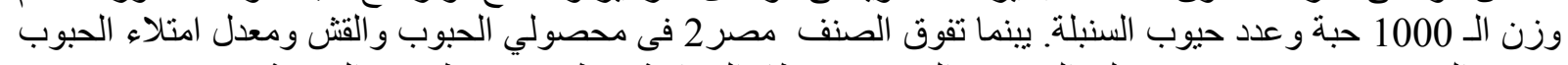

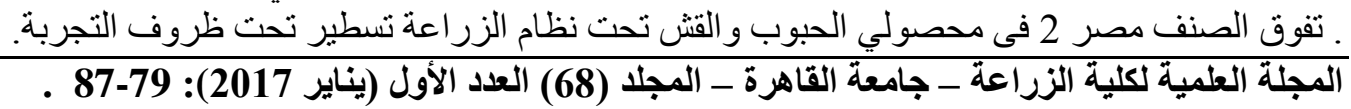

